\title{
Review \\ Developments in the scientific and clinical understanding of the spondyloarthritides
}

Joachim Sieper

Department of Rheumatology, Campus Benjamin Franklin, Charité, Hindenburgdamm 30, 12200 Berlin, Germany

Corresponding author: Joachim Sieper, joachim.sieper@charite.de

Published: 30 January 2009

This article is online at http://arthritis-research.com/content/11/1/208

(c) 2009 BioMed Central Ltd
Arthritis Research \& Therapy 2009, 11:208 (doi:10.1186/ar2562)

better criteria for early diagnosis, and finally to get a better understanding of the pathogenetic mechanisms in SpA. The research and the rapid development in the last 10 years have been preferentially focused on axial SpA, with ankylosing spondylitis (AS) as the most relevant subtype. Considerable progress could also be made in psoriatic arthritis (PsA), which overlaps with the SpA group. However, a thorough discussion of these results would go beyond the scope of this article and will have to be dealt with elsewhere. Therefore, the following discussion will focus on axial SpA and will touch only briefly on peripheral SpA.

\section{The concept/classification of spondyloarthritides}

The SpA comprise AS, reactive arthritis, arthritis/spondylitis associated with psoriasis, and arthritis/spondylitis associated with inflammatory bowel disease (IBD). The main links between these conditions are the association with HLA-B27, the same pattern of peripheral joint involvement with an asymmetrical pauciarticular arthritis predominantly of the lower limbs, and the possible occurrence of sacroiliitis, spondylitis, enthesitis, dactylitis, and uveitis [1]. The SpA can also be divided into patients with predominantly axial and predominantly peripheral $\mathrm{SpA}$, a classification that is preferred by this author and others [2,3], with an overlap between the two parts in about $20 \%$ to $40 \%$ of cases. By means of such a classification, the presence or absence of evidence for a preceding gastrointestinal or urogenital infection, psoriasis, or IBD is recorded but does not result in a different classification.

The term PsA comprises different subtypes, including arthritis of the finger joints. All subgroups can be classified by the recently published Classification Criteria for Psoriatic Arthritis (CASPAR) [4]. However, only patients with axial manifesunmet need to diagnose

AS = ankylosing spondylitis; ASAS = Assessment in SpondyloArthritis International Society; ASAS40 = Assessment in SpondyloArthritis International Society 40\% improvement criteria; BASDAI = Bath Ankylosing Spondylitis Disease Activity Index; ESSG = European Study Group for Spondyloarthropathies; IBD = inflammatory bowel disease; IL-23 = interleukin-23; MRI = magnetic resonance imaging; NSAID = nonsteroidal antiinflammatory drug; $\mathrm{PsA}=$ psoriatic arthritis; $\mathrm{SI}=$ sacroiliac; $\mathrm{SpA}=$ spondyloarthritides; $\mathrm{TNF}=$ tumor necrosis factor. 
tations and/or asymmetrical peripheral arthritis predominantly of the lower limbs would fit into the pattern suggested by the European Study Group for Spondyloarthropathies (ESSG) [2]. In contrast to earlier reports, the polyarthritic type nowadays seems to be more frequent than the oligoarthritic one [5]. Thus, patients with PsA could probably be divided into SpA type and non-SpA type, although synovial histopathological data from peripheral joints indicate that any type of PsA resembles other SpA subtypes more than rheumatoid arthritis. Further studies are necessary to better define the exact relationship between SpA and PsA [6].

In 1991, the ESSG proposed classification criteria for the whole group of $\mathrm{SpA}$, including the new subgroup of undifferentiated $\mathrm{SpA}$ with features specific for the SpA but not fulfilling the diagnostic criteria for one of the defined diseases [2]. The leading clinical symptoms for all subsets of $\mathrm{SpA}$ are inflammatory back pain and/or an asymmetrical arthritis predominantly of the lower limbs. These criteria already used the division into axial and peripheral SpA. The Amor criteria published in 1990 by Amor and colleagues [7] cover the whole spectrum of SpA. Less frequently, enthesitis or uveitis can be the leading symptom. These patients would not fulfill the ESSG criteria but could be captured by the Amor criteria. To demonstrate that $\mathrm{SpA}$ is an inflammatory disease, the term 'spondyloarthritis' instead of 'spondyloarthropathies' is now generally accepted.

\section{The need for early diagnosis in axial spondyloarthritides}

AS is the most relevant subtype for all patients with predominantly spinal symptoms and is regarded together with $\mathrm{PsA}$ as the SpA with the most severe outcome. Its prevalence has been estimated to be between $0.2 \%$ and $0.9 \%[1,8]$ and the disease normally starts in the second decade of life. The male-to-female ratio has been estimated more recently to be around $2: 1$. In these patients, back pain is the leading clinical symptom, which presents typically as inflammatory back pain that is characterized by morning stiffness and improvement by exercise [9]. In $90 \%$ or more cases, the disease starts with a sacroiliitis. Further in the course of the disease, the whole spine can be affected with spondylitis, spondylodisciitis, and arthritis of the small intervetebral joints [9]. However, it is important to stress that not all AS patients have or develop syndesmophytes. Even in patients with longer-standing disease, syndesmophytes are present in only about $50 \%$ of cases and only a smaller percentage of these patients develop the typical clinical picture of patients with an ankylosed spine, where the name AS comes from. The term AS was introduced around 1900 at a time when a diagnosis could be made only on the basis of the clinical experience, without the help of imaging or laboratory results. The term axial SpA, covering patients early in the course of the disease and patients with a less progressive course, seems to be more adequate [3], whereas the term AS should be reserved for the more advanced 'ankylosed' phase of the disease.
Currently, there is an unacceptably long delay, from 5 to 10 years, between the first occurrence of AS symptoms and a diagnosis of AS $[10,11]$. Two major reasons can be named for such a delay: (a) There is certainly a low awareness of AS among nonrheumatologists and it can be seen as a major challenge for any physician in primary care to think of and to identify patients with inflammatory spine disease among the large group of patients with chronic back pain, most often of another origin. (b) Radiographic sacroiliitis grade 2 bilaterally or grade 3 or 4 unilaterally is usually a requirement for making the diagnosis of AS according to the modified New York criteria [12]. However, radiographic changes indicate chronic changes and damage of the bone and are the consequence of inflammation and not active inflammation itself. Since AS is a slowly progressing disease as far as radiographic changes are concerned, definite sacroiliitis on plain radiographs appears relatively late, frequently taking several years of continuous or relapsing inflammation [3]. In early disease without definite radiographic changes, active inflammation of sacroiliac (SI) joints can normally be visualized using MRI technology. Clinical experience as well as limited data suggest that a good proportion of patients with inflammation of $\mathrm{SI}$ joints on MRI and yet normal or suspicious radiographs will develop radiographic sacroiliitis later on and therefore evolve to AS [13]. We have proposed, therefore, to consider all patients with SpA with predominantly axial involvement irrespective of the presence or absence of radiographic changes as belonging to one disease continuum [3]. Furthermore, we have proposed to use the term 'preradiographic' or 'nonradiographic axial SpA' for the group of patients with early axial SpA [3,14]. Such terms are also preferable to 'undifferentiated (axial) SpA' because this subgroup is now well defined and can be diagnosed without problems (see below).

According to this reasoning, new criteria for the diagnosis and classification of axial SpA are needed. In such criteria, radiographic sacroiliitis as defined by the modified New York criteria will be part of but not essential for the diagnosis. For patients with nonradiographic sacroiliitis, active inflammation as shown by MRI should be an important parameter. In general, a combination of several clinical (such as inflammatory back pain, enthesitis, uveitis, or peripheral arthritis), laboratory (such as HLA-B27 or C-reactive protein), and imaging ( $\mathrm{x}$-rays or MRI) parameters is necessary for an early diagnosis [3]. We have calculated so-called post-test probabilities which are dependent on the presence or absence of these criteria in patients presenting with chronic back pain and a suspected diagnosis of axial SpA and which can also be used in daily clinical practice [3]. Because of the relatively low pretest probability of about $5 \%$, a combination of several positive parameters is normally necessary to have a diagnosis of axial SpA among patients with chronic low back pain seen by primary care physicians [15]. In 2004, the ASAS group started an international project on the development of new classification criteria for axial and peripheral SpA. Based on 
an analysis of data from more than 600 patients with predominant axial symptoms, the ASAS group has voted on new criteria for axial SpA which most probably will be published early in 2009. In these criteria, sacroiliitis detected either by $\mathrm{x}$-rays or by MRI will play a dominant role. The exact diagnostic value of active inflammatory sacroiliitis as shown by MRI has to be evaluated further in prospective studies. A similar process for the development of peripheral SpA criteria is in progress. This project and the resulting new criteria have been an important milestone for several reasons: (a) they will allow better diagnosis and classification of patients with nonradiographic sacroiliitis, (b) they establish the concept that patients with nonradiographic and radiographic sacroiliitis have the same disease, and finally (c) they will create the basis for treatment of patients with early axial SpA with TNF blockers and other drugs.

\section{Screening for axial spondyloarthritides among patients with chronic back pain in primary care}

Besides establishing criteria such as the early diagnosis of AS strategies, of similar relevance to making an earlier diagnosis is how to alert the primary care physician on when to consider inflammatory spine disease in patients with chronic back pain, and when to refer these patients to the rheumatologist for a final diagnosis. Recently, we proposed easy-to-apply screening parameters for early referral of AS patients by primary care physicians. Such parameters have to be relatively sensitive and specific for the disease in question, have to be easy to apply by the nonspecialist, and should not be too expensive. In a study we performed in the Berlin area of Germany in patients who had chronic back pain for more than 3 months and who were younger than 45 years at the start of symptoms, we asked all orthopedists and primary care physicians to refer to an early axial SpA clinic those patients who fulfilled one or more of the following criteria: fulfilling the clinical symptom of inflammatory back pain, being positive for HLA-B27, or showing evidence of sacroiliitis by imaging [11]. Analyzing 350 referred patients, we could show that a final diagnosis of axial SpA could be made in about $45 \%$, half of them with nonradiographic sacroiliitis. These data clearly indicate that such a screening approach is feasible and effective and that patients with nonradiographic axial SpA constitute a substantial part of the whole group of patients with axial SpA.

\section{Management of axial spondyloarthritis}

The many recent treatment trials that have been performed in AS were possible only because outcome parameters regarding clinical symptoms [16], MRI [17], and x-rays [18] have been better defined over the last 10 years. The ASAS group has further defined criteria for 20\% improvement [19], 40\% improvement [20], and partial remission [19] (the ASAS20, ASAS40, and ASAS partial remission criteria, respectively) of clinical symptoms. Andrei Calin, of Bath, UK, had started this kind of work in the early 90s with the definition of the Bath Ankylosing Spondylitis Disease Activity Index (BASDAI) [21], the Bath Ankylosing Spondylitis Functional Index (BASFI), and the Bath Ankylosing Spondylitis Metrology Index (BASMI) (all on a scale between $0=$ no change and $10=$ worst change), which are all still in use. Work is currently in progress to further improve some of these outcome parameters.

Recently, ASAS/European League Against Rheumatism recommendations on the management of $A S$, which are based on a thorough analysis of the available literature and on a meeting of SpA experts, were published [22]. Again, because most of these studies have been performed in AS, these recommendations focus on AS. The recommendations are divided into AS patients with predominantly axial and those with predominantly peripheral manifestations. For all manifestations, nonmedical therapy such as physical therapy and patient education should be part of any management program for patients; surgery plays a role in selected cases only. Pharmaceutical treatment is the most important part of the management. For patients with predominantly axial manifestations, only two types of drugs have been proven to be effective: nonsteroidal anti-inflammatory drugs (NSAIDs) and TNF blockers. Disease modifying antirheumatic drugs that are well established for the treatment of rheumatoid arthritis, such as sulfasalazine $[23,24]$, methotrexate $[11,25]$, or leflunomide [26], have been shown to be of no value for the treatment of AS. Only sulfasalazine should be tried before patients with active disease are treated with a TNF blocker if the peripheral manifestations such as arthritis or enthesitis prevail [22].

\section{Nonsteroidal anti-inflammatory drug treatment}

The NSAIDs are still regarded as the cornerstone of pharmacological intervention for AS with a good anti-inflammatory capacity, reducing pain and stiffness rapidly after 48 to 72 hours $[19,27]$. Nonetheless, patients frequently are not treated with a full dosis of NSAIDs and/or are not treated continuously despite being symptomatic. A major reason for this is that both patients and treating physicians often are concerned about the toxicity of a continuous NSAID treatment. We recently summarized and discussed the benefits and risks of NSAID treatment in AS [27]. Besides a good efficacy on signs and symptoms, there is evidence that continuous therapy with NSAIDs might stop the new formation of syndesmophytes in the spine, as reported recently [28]. It is not clear at the moment whether such a possible effect can be explained by the suppression of inflammation or rather by a direct inhibition of osteoblast activity by NSAIDs through the suppression of prostaglandins [29]. There is now a sufficient amount on data available on the risks of long-term treatment with NSAIDs in several large non-AS trials. However, because in these trials patients were older and had more comorbidities than AS patients, it seems to be justifiable to draw some conclusions based on these trials: in patients younger than 60 years and without gastrointestinal or cardiovascular comorbidities, the probability is $1 \%$ or less for developing serious gastrointestinal or cardiovascular side 
effects when treated with a full dosis of an NSAID for 1 year. Also, the risks for renal and liver side effects are known and seem to be acceptable. Thus, when AS patients are active, they should be treated with a sufficient dosis of NSAIDs (continuously, if necessary) [27]. Certainly, patients have to be informed about and monitored for potential toxicity.

\section{Tumor necrosis factor blocker treatment}

It can be estimated that about $20 \%$ of AS patients are still active despite an optimal treatment with NSAIDs. This means that the demonstration of the good or very good efficacy of TNF blockers in the treatment of patients with active AS can be regarded as a breakthrough in the therapy of these AS patients. These drugs not only improve signs and symptoms rapidly and in a high percentage of patients, but also normalize acute-phase reactants and reduce acute inflammation in $\mathrm{SI}$ joints and spine as shown by MRI. There are three biologic agents targeting TNF- $\alpha$ which have been shown to be effective for the treatment of AS [30-32] and which have been approved for this indication both in the European Community and the US. Inflixmab is given as an intravenous infusion over the course of 2 hours in a dose of $5 \mathrm{mg} / \mathrm{kg}$ intially at weeks 0,1 and 6 and then every 6 to 8 weeks, etanercept is given subcutaneously at a dose of $50 \mathrm{mg}$ once or 25 mg twice a week, and adalimumab is given at a dose of $40 \mathrm{mg}$ subcutaneously every other week. The three TNFblocking agents have similar efficacies on the rheumatic symptoms: about $50 \%$ of patients reach a $50 \%$ improvement of their disease activity as measured by the BASDAI. Impressive reductions of inflammatory lesions either in the SI joints or in the spine have been demonstrated for all three TNF blockers [33]. Interestingly, there is still a further decrease of inflammation if patients are treated over the course of 2 years, although in a small proportion of patients inflammation as seen by MRI is not suppressed completely [34]. AS and related SpA seem to be the disease for which TNF blockers are most effective, probably more effective than in rheumatoid arthritis [35]. So far, long-term follow-up of AS patients treated with TNF blockers has been published up to 5 years, showing a good long-term efficacy if treatment is continued. After 3 years, about $70 \%$ of the initial patients are still treated. However, when treatment was stopped, nearly all of these patients with long-standing active disease flared [36]. It has to be shown whether this is also the case when patients are treated earlier.

Currently, there is no evidence that a combination of TNF blocker with a conventional disease-modifying antirheumatic drug is superior to treatment of AS with a TNF blocker alone. Most of the patients in the studies were indeed treated with TNF blocker monotherapy. A recent study comparing infliximab alone versus infliximab plus methotrexate did not see a significant difference between the two groups regarding efficacy and side effects [37].

Extrarheumatic manifestations or comorbidities such as uveitis, psoriasis, or IBD are present or have occurred in the past in $40 \%$ to $50 \%$ of AS patients [9]. Thus, it is also of interest whether the three TNF blockers differ in their efficacies regarding these manifestations. Both monoclonal antibodies have been shown to be effective for the treatment of Crohn's disease, and infliximab has been shown to be effective for ulcerative colitis, whereas etanercept does not work in IBD. When it was investigated whether TNF blockers reduce flares or new onset of IBD in AS patients treated for their rheumatic manifestations, infliximab was clearly superior to etanercept whereas the number of patients treated with adalimumab was too small in this meta-analysis to allow any further conclusions [38]. In another meta-analysis of trials from AS patients treated with TNF blockers, both infliximab and etanercept reduced flares of uveitis but infliximab was more effective [39]. Based on data from a small retrospective study and from one large but uncontrolled observational study [40], adalimumab seems to reduce flares of uveitis. All three TNF blockers are effective for psoriasis, although infliximab shows the best efficacy on the skin in the dosis normally used for the treatment of AS [41].

When it was analyzed which parameters predict a response to TNF blockers best, short disease duration and/or young age were the best predictors [14,42], indicating that, in patients with long-lasting disease, causes other than inflammation contribute to the clinical symptoms. An elevated Creactive protein and active inflammation as shown by $M R$ were also predictive but to a lesser extent [42]. An international ASAS consensus statement for the use of anti-TNF agents in AS patients, which was published in 2003 and updated in 2006 [43], specifies the management recommendations for the use of TNF blockers in patients with active AS.

\section{Tumor necrosis factor blockers in early nonradiographic axial spondyloarthritides}

Because AS patients with a shorter disease duration respond better to TNF blocker treatment and because there can be ongoing active inflammation in the SI joints and/or spine for some time before radiographic changes become visible, it was logical to ask whether and how well active axial SpA patients with nonradiographic sacroiliitis respond to treatment with TNF blocker. If these patients were treated with adalimumab for 12 weeks, an ASAS40 response was achieved in 54\% of patients versus $12 \%$ in the placebo group, an effect that was maintained for 1 year of treatment for the whole group after the placebo patients were also switched to adalimumab [14]. In the subgroup of patients with a disease duration of less than 3 years, such a major response was even achieved in $80 \%$ of patients. A similar result was reported for patients with early axial SpA with a symptom duration of less than 3 years when treated with infliximab [44]. In this study, a partial remission was even achieved in $55 \%$ of patients. Thus, treatment with a TNF blocker seems to be even more effective the earlier the patients are treated. Preliminary results from these two studies indicate that the majority of patients relapse if treatment is stopped. It remains to be seen 
whether long-lasting drug-free remission can be achieved if patients are treated even earlier.

\section{Immunopathology and structural damage in ankylosing spondylitis}

Many recent MRI studies and older pathological investigations [45] suggest that the primary target of the immune response is at the cartilage/bone interface, including the insertion of tendon and ligaments at the bone (enthesis) $[46,47]$. Such an immunopathology most probably would differ from rheumatoid arthritis, in which inflammation occurs primarily in the synovium. We recently provided further evidence for this hypothesis, showing that the presence of mononuclear cell infiltrates and osteoclasts depends on the presence of cartilage on the joint surface in AS patients [48].

In addition to inflammation, AS is characterized by new bone formation with the possible consequence of bone fusion, most frequently found in the axial skeleton in the form of syndesmophytes. How inflammation and new bone formation are coupled in AS and whether AS is a disease of excessive new bone formation or whether this is only part of a physiological repair mechanism have been questions for a long time. We recently argued, based on MRI studies and especially on older pathological studies [45], that structural damage happens in two steps: first, inflammation causes erosive structural damage and these bony defects are then filled up with (fibrous) repair tissue; second, this repair tissue is subsequently ossified. If this is true, new bone formation would not occur without previous erosive damage by inflammation [29].

Interestingly, in these pathological studies [45], it was already observed that new bone formation goes along with the disappearance of inflammation or with only a low grade of inflammation. This is in line with recent functional studies that could show that inflammation itself inhibits osteoproliferation. A proinflammatory cytokine such as TNF- $\alpha$ causes bone resorption by inducing the expression of DKK-1. This leads to a suppression of the Wnt pathway, which communicates signals for osteoblastogenesis and new bone formation [49]. Inhibition of TNF- $\alpha$ and/or DKK-1 then induces new bone. Thus, TNF blockers do not inhibit osteoproliferation at all but rather stimulate new bone formation by taking away the inhibitory effect of TNF- $\alpha$ on osteoblasts. This was also demonstrated in a mouse model of ankylosis in which the TNF- $\alpha$ blocker etanercept did not prevent new bone formation, although inflammation was effectively suppressed [50]. These findings and considerations might also explain why the formation of new syndesmophytes was not inhibited over the course of a 2-year treatment with a TNF blocker in comparison with a historical control group [51]. It remains to be seen whether such new bone formation can be prevented if TNF blocker treatment is started early enough before the occurrence of erosive structural damage.

\section{Pathogenesis of spondyloarthritis}

A major breakthrough in the research on the pathogenesis of $\mathrm{AS}$ and related $\mathrm{SpA}$ was the reported strong association of the disease with HLA-B27 in 1973 [52]. However, intensive research over more than three decades has not clarified the functional role of the HLA-B27 molecule in the pathogenetic process. In the center of the discussion about the pathogenesis of the SpA is still the interaction between bacteria and HLA-B27 because of the known triggering bacteria in reactive arthritis [53] and the association with IBD in which the immune system can interact with local gut bacteria due to a damaged mucosa. Different hypotheses such as the arthritogenic peptide hypothesis [54], the 'HLAB27 misfolding hypothesis' [55], and the induction of an HLA-B27-mediated autoimmune response directed against cartilage [56] have been proposed and investigated, but none of them has been conclusive so far. Interestingly, among the more than $20 \mathrm{HLA}-\mathrm{B} 27$ subtypes, some such as HLA$B^{\star} 2706$ and HLA-B*2709 are not at all associated or are clearly less associated with the disease, suggesting that the minor molecular differences between the molecules might be the key for a better understanding of the pathogenesis [57].

Susceptibility to AS has been estimated to be greater than $90 \%$ genetically determined and therefore it has been suggested that there might be not a single environmental factor, such as one bacterium, but rather ubiquitous environmental factors [58]. Most recently, two new genetic loci, besides HLA-B27, were shown to be associated with AS: the interleukin-23 (IL-23) receptor, which is involved in the Th 17 pathway of chronic immune responses, and ARTS1, an enzyme that is relevant for the processing of peptides in the cytoplasm [59]. The relative contributions of these genes to the susceptibility to AS can be compared by using the population-attributable risk fraction statistic, which is $90 \%$ for HLA-B27, 26\% for ARTS1, and 9\% for IL-23. It remains to be seen what the functional relevance of these associations is and whether this very interesting new discovery helps us to understand the pathogenesis better. In conclusion, over the last decade, treatment has been moving from showing any efficacy at all in patients with active SpA to earlier treatment with the final aim of inducing remission and preventing structural damage. A curative treatment is not yet available because pathogenesis is still poorly understood.

\section{Future perspectives in spondyloarthritis}

Although major progress has been achieved in SpA over the last 10 years, there is still a long way to go to find a curative treatment that results in drug-free long-lasting remission. In the short term, how patients with early SpA should be treated with the highly effective TNF blockers and whether continuous remission can be achieved if patients are treated very early are questions that have to be investigated. Furthermore, it is a burning question whether new bone formation can be prevented if inflammation is suppressed early enough or whether both inflammation and new bone formation have to 


\section{The Scientific Basis of Rheumatology: years A Decade of Progress}

This article is part of a special collection of reviews, The Scientific Basis of Rheumatology: A Decade of Progress, published to mark Arthritis Research \& Therapy's 10 th anniversary.

Other articles in this series can be found at: http://arthritis-research.com/sbr

be targeted simultaneously. Targeted therapies other than TNF blockers have to be tested systematically because not all patients respond to TNF blockers and normally disease activity relapses if treatment is stopped. Although peripheral $\mathrm{SpA}$ is less frequent and often less severe compared with axial SpA, there is a great medical need for the performance of treatment trials and the establishment of effective therapies for these patients. Finally, only a better understanding of the pathogenesis will give the possibility of finding a cure. Thus, both clinical and basic science research have to be intensified and the translational aspects have to be strengthened in the next decade with the aim of surpassing even the progress seen in the last decade.

\section{Competing interests}

JS has received reimbursements, fees and funding from Abbott, Pfizer, Schering-Plough and Wyeth. There was no financing of this manuscript.

\section{References}

1. Sieper J, Rudwaleit M, Khan MA, Braun J: Concepts and epidemiology of spondyloarthritis. Best Pract Res Clin Rheumatol 2006, 20:401-417.

2. Dougados $M$, van der Linden $S$, Juhlin $R$, Huitfeldt $B$, Amor $B$, Calin A, Cats A, Dijkmans B, Olivieri I, Pasero G, Vegs E, Zeioller $\mathrm{H}$ : The European Spondylarthropathy Study Group preliminary criteria for the classification of spondylarthropathy. Arthritis Rheum 1991, 34:1218-1227.

3. Rudwaleit M, Khan MA, Sieper J: The challenge of diagnosis and classification in early ankylosing spondylitis: do we need new criteria? Arthritis Rheum 2005, 52:1000-1008.

4. Taylor W, Gladman D, Helliwell P, Marchesoni A, Mease P, Mielants $\mathrm{H}$ : Classification criteria for psoriatic arthritis: development of new criteria from a large international study. Arthritis Rheum 2006, 54:2665-2673.

5. Helliwell PS, Porter G, Taylor WJ: Polyarticular psoriatic arthritis is more like oligoarticular psoriatic arthritis, than rheumatoid arthritis. Ann Rheum Dis 2007, 66:113-117.

6. Kruithof E, Baeten D, De Rycke L, Vandooren B, Foell D, Roth J, Canete JD, Boots AM, Veys EM, De Keyser F: Synovial histopathology of psoriatic arthritis, both oligo- and polyarticular, resembles spondyloarthropathy more than it does rheumatoid arthritis. Arthritis Res Ther 2005, 7:R569-580.

7. Amor B, Dougados M, Mijiyawa M: [Criteria of the classification of spondylarthropathies]. Rev Rhum Mal Osteoartic 1990, 57: 85-89.

8. Braun J, Bollow M, Remlinger G, Eggens U, Rudwaleit M, Distler A, Sieper J: Prevalence of spondylarthropathies in HLA-B27 positive and negative blood donors. Arthritis Rheum 1998, 41: 58-67.

9. Braun J, Sieper J: Ankylosing spondylitis. Lancet 2007, 369: 1379-1390.

10. Feldtkeller $E$, Khan $M A$, van der Heijde $D$, van der Linden $S$, Braun $\mathrm{J}$ : Age at disease onset and diagnosis delay in HLA-B27 negative vs. positive patients with ankylosing spondylitis. Rheumatol Int 2003, 23:61-66.

11. Haibel $H$, Brandt HC, Song $I H$, Brandt A, Listing J, Rudwaleit $M$, Sieper J: No efficacy of subcutaneous methotrexate in active ankylosing spondylitis: a 16-week open-label trial. Ann Rheum Dis 2007, 66:419-421.

12. van der Linden S, Valkenburg HA, Cats A: Evaluation of diagnostic criteria for ankylosing spondylitis. A proposal for modification of the New York criteria. Arthritis Rheum 1984, 27: 361-368.

13. Oostveen J, Prevo R, den Boer J, van de Laar M: Early detection of sacroiliitis on magnetic resonance imaging and subsequent development of sacroiliitis on plain radiography. A prospective, longitudinal study. J Rheumatol 1999, 26:19531958.

14. Haibel H, Rudwaleit M, Listing J, Heldmann F, Wong RL, Kupper $\mathrm{H}$, Braun J, Sieper J: Efficacy of adalimumab in the treatment of axial spondylarthritis without radiographically defined sacroiliitis: results of a twelve-week randomized, doubleblind, placebo-controlled trial followed by an open-label extension up to week fifty-two. Arthritis Rheum 2008, 58:19811991.

15. Underwood MR, Dawes $P$ : Inflammatory back pain in primary care. Br J Rheumatol 1995, 34:1074-1077.

16. van der Heijde D, Calin A, Dougados M, Khan MA, van der Linden $\mathrm{S}$, Bellamy N: Selection of instruments in the core set for DCART, SMARD, physical therapy, and clinical record keeping in ankylosing spondylitis. Progress report of the ASAS Working Group. Assessments in Ankylosing Spondylitis. J Rheumatol 1999, 26:951-954.

17. Braun J, Baraliakos X, Golder W, Brandt J, Rudwaleit M, Listing J, Bollow M, Sieper J, Van Der Heijde D: Magnetic resonance imaging examinations of the spine in patients with ankylosing spondylitis, before and after successful therapy with infliximab: evaluation of a new scoring system. Arthritis Rheum 2003, 48:1126-1136.

18. Wanders AJ, Landewe RB, Spoorenberg A, Dougados M, van der Linden S, Mielants H, van der Tempel H, van der Heijde DM: What is the most appropriate radiologic scoring method for ankylosing spondylitis? A comparison of the available methods based on the Outcome Measures in Rheumatology Clinical Trials filter. Arthritis Rheum 2004, 50:2622-2632.

19. Anderson JJ, Baron G, van der Heijde D, Felson DT, Dougados M: Ankylosing spondylitis assessment group preliminary definition of short-term improvement in ankylosing spondylitis. Arthritis Rheum 2001, 44:1876-1886.

20. Rudwaleit M, Listing J, Brandt J, Braun J, Sieper J: Prediction of a major clinical response (BASDAl 50) to tumour necrosis factor alpha blockers in ankylosing spondylitis. Ann Rheum Dis 2004, 63:665-670.

21. Garrett $S$, Jenkinson T, Kennedy LG, Whitelock H, Gaisford P, Calin A: A new approach to defining disease status in ankylosing spondylitis: the Bath Ankylosing Spondylitis Disease Activity Index. J Rheumatol 1994, 21:2286-2291.

22. Zochling J, van der Heijde D, Burgos-Vargas R, Collantes E, Davis JC Jr, Dijkmans B, Dougados M, Géher P, Inman RD, Khan MA, Kvien TK, Leirisalo-Repo M, Olivieri I, Pavelka K, Sieper J, Stucki G, Sturrock RD, van der Linden S, Wendling $D$, Böhm $H$, van Royen BJ, Braun J; 'ASsessment in AS' international working group; European League Against Rheumatism: ASAS/EULAR recommendations for the management of ankylosing spondylitis. Ann Rheum Dis 2006, 65:442-452.

23. Braun J, Zochling J, Baraliakos $X$, Alten $R$, Burmester G, Grasedyck K, Brandt J, Haibel H, Hammer M, Krause A, Mielke F, Tony HP, Ebner W, Gömör B, Hermann J, Zeidler H, Beck E, Baumgaertner M, Sieper J: Efficacy of sulfasalazine in patients with inflammatory back pain due to undifferentiated spondyloarthritis and early ankylosing spondylitis: a multicentre randomized controlled trial. Ann Rheum Dis 2006, 65:1147-1153.

24. Chen J, Liu C: Sulfasalazine for ankylosing spondylitis. Cochrane Database Syst Rev 2005(2):CD004800. 
25. Chen J, Liu C: Methotrexate for ankylosing spondylitis. Cochrane Database Syst Rev 2004(3):CD004524.

26. Haibel H, Rudwaleit M, Braun J, Sieper J: Six months open label trial of leflunomide in active ankylosing spondylitis. Ann Rheum Dis 2005, 64:124-126.

27. Song IH, Poddubnyy DA, Rudwaleit M, Sieper J: Benefits and risks of ankylosing spondylitis treatment with nonsteroidal antiinflammatory drugs. Arthritis Rheum 2008, 58:929-938.

28. Wanders A, Heijde D, Landewe R, Behier JM, Calin A, Olivieri I, Zeidler $\mathrm{H}$, Dougados $\mathrm{M}$ : Nonsteroidal antiinflammatory drugs reduce radiographic progression in patients with ankylosing spondylitis: a randomized clinical trial. Arthritis Rheum 2005, 52:1756-1765.

29. Sieper J, Appel H, Braun J, Rudwaleit M: Critical appraisal of assessment of structural damage in ankylosing spondylitis: implications for treatment outcomes. Arthritis Rheum 2008, 58:649-656

30. Braun J, Brandt J, Listing J, Zink A, Alten R, Golder W, GromnicaIhle E, Kellner H, Krause A, Schneider M, Sörensen H, Zeidler H, Thriene W, Sieper J: Treatment of active ankylosing spondylitis with infliximab: a randomised controlled multicentre trial. Lancet 2002, 359:1187-1193.

31. Davis JC Jr., Van Der Heijde D, Braun J, Dougados M, Cush J, Clegg DO, Kivitz A, Fleischmann R, Inman R, Tsuji W: Recombinant human tumor necrosis factor receptor (etanercept) for treating ankylosing spondylitis: a randomized, controlled trial. Arthritis Rheum 2003, 48:3230-3236.

32. van der Heijde D, Kivitz A, Schiff MH, Sieper J, Dijkmans BA, Braun J, Dougados M, Reveille JD, Wong RL, Kupper H, Davis JC Jr.; ATLAS Study Group: Efficacy and safety of adalimumab in patients with ankylosing spondylitis: results of a multicenter, randomized, double-blind, placebo-controlled trial. Arthritis Rheum 2006, 54:2136-2146.

33. Braun J, Landewe R, Hermann KG, Han J, Yan S, Williamson P, van der Heijde D: Major reduction in spinal inflammation in patients with ankylosing spondylitis after treatment with infliximab: results of a multicenter, randomized, double-blind, placebo-controlled magnetic resonance imaging study. Arthritis Rheum 2006, 54:1646-1652.

34. Sieper J, Baraliakos X, Listing J, Brandt J, Haibel H, Rudwaleit M, Braun $\mathrm{J}$ : Persistent reduction of spinal inflammation as assessed by magnetic resonance imaging in patients with ankylosing spondylitis after 2 yrs of treatment with the antitumour necrosis factor agent infliximab. Rheumatology (Oxford) 2005, 44:1525-1530.

35. Heiberg MS, Nordvag BY, Mikkelsen K, Rodevand E, Kaufmann C, Mowinckel P, Kvien TK: The comparative effectiveness of tumor necrosis factor-blocking agents in patients with rheumatoid arthritis and patients with ankylosing spondylitis: a six-month, longitudinal, observational, multicenter study. Arthritis Rheum 2005, 52:2506-2512.

36. Baraliakos X, Listing J, Brandt J, Rudwaleit M, Sieper J, Braun J: Clinical response to discontinuation of anti-TNF therapy in patients with ankylosing spondylitis after 3 years of continuous treatment with infliximab. Arthritis Res Ther 2005, 7:R439444

37. Breban $M$, Ravaud $P$, Claudepierre $P$, Baron G, Henry YD, Hudry C, Euller-Ziegler L, Pham T, Solau-Gervais E, Chary-Valckenaere I, Marcelli C, Perdriger A, Le Loët X, Wendling D, Fautrel B, Fournié B, Combe B, Gaudin P, Jousse S, Mariette X, Baleydier A, Trape $G$, Dougados $M$; French Ankylosing Spondylitis Infliximab Network: Maintenance of infliximab treatment in ankylosing spondylitis: results of a one-year randomized controlled trial comparing systematic versus on-demand treatment. Arthritis Rheum 2008, 58:88-97

38. Braun J, Baraliakos X, Listing J, Davis J, van der Heijde D, Haibel $\mathrm{H}$, Rudwaleit M, Sieper J: Differences in the incidence of flares or new onset of inflammatory bowel diseases in patients with ankylosing spondylitis exposed to therapy with anti-tumor necrosis factor alpha agents. Arthritis Rheum 2007, 57:639647.

39. Braun J, Baraliakos X, Listing J Sieper J: Decreased incidence of anterior uveitis in patients with ankylosing spondylitis treated with the anti-tumor necrosis factor agents infliximab and etanercept. Arthritis Rheum 2005, 52:2447-2451.

40. Rudwaleit M, Rodevand E, Holck P, Vanhoof J, Kron M, Kary S, Kupper $\mathrm{H}$ : Adalimumab effectively reduces the rate of anterior uveitis flares in patients with active ankylosing spondylitis: results of a prospective open-label study. Ann Rheum Dis 2008, Jul 28. [Epub ahead of print].

41. Kavanaugh AF, Ritchlin CT: Systematic review of treatments for psoriatic arthritis: an evidence based approach and basis for treatment guidelines. J Rheumato/ 2006, 33:1417-1421.

42. Rudwaleit M, Schwarzlose S, Hilgert ES, Listing J, Braun J, Sieper $\mathrm{J}$ : MRI in predicting a major clinical response to anti-tumour necrosis factor treatment in ankylosing spondylitis. Ann Rheum Dis 2008, 67:1276-1281.

43. Braun J, Davis J, Dougados M, Sieper J, van der Linden S, van der Heijde D: First update of the international ASAS consensus statement for the use of anti-TNF agents in patients with ankylosing spondylitis. Ann Rheum Dis 2006, 65:316-320.

44. Barkham N, Keen H, Coates L, O'Connor P, Hemsor EMA, Fraser AD, Cawkwell P, McGonagle D, Emery P: A randomised controlled trial of infliximab shows clinical and MRI efficacy in patients with HLA-B27 positive very early ankylosing spondylitis [abstract]. Arthritis Rheum 2007, 56 (Supplement):L11.

45. Cruickshank B: Lesions of cartilaginous joints in ankylosing spondylitis. J Pathol Bacteriol 1956, 71:73-84.

46. McGonagle D, Gibbon W, Emery P: Classification of inflammatory arthritis by enthesitis. Lancet 1998, 352:1137-1140.

47. Maksymowych WP: Ankylosing spondylitis-at the interface of bone and cartilage. J Rheumato/ 2000, 27:2295-2301.

48. Appel H, Kuhne M, Spiekermann S, Kohler D, Zacher J, Stein H, Sieper J, Loddenkemper C: Immunohistochemical analysis of hip arthritis in ankylosing spondylitis: evaluation of the bonecartilage interface and subchondral bone marrow. Arthritis Rheum 2006, 54:1805-1813.

49. Diarra D, Stolina M, Polzer K, Zwerina J, Ominsky MS, Dwyer D, Korb A, Smolen J, Hoffmann M, Scheinecker C, van der Heide D, Landewe R, Lacey D, Richards WG, Schett G: Dickkopf-1 is a master regulator of joint remodeling. Nat Med 2007, 13:156163.

50. Lories RJ, Derese I, De Bari C, Luyten FP: Evidence for uncoupling of inflammation and joint remodeling in a mouse model of spondyloarthritis. Arthritis Rheum 2007, 56:489-497.

51. van der Heijde D, Landewe R, Einstein S, Ory P, Vosse D, Ni L Lin SL, Tsuji W, Davis JC Jr.: Radiographic progression of ankylosing spondylitis after up to two years of treatment with etanercept. Arthritis Rheum 2008, 58:1324-1331.

52. Brewerton DA, Hart FD, Nicholls A, Caffrey M, James DC, Sturrock RD: Ankylosing spondylitis and HL-A 27. Lancet 1973, 1: 904-907.

53. Sieper J, Braun J, Kingsley GH: Report on the Fourth International Workshop on Reactive Arthritis. Arthritis Rheum 2000, 43:720-734

54. Ugrinovic S, Mertz A, Wu P, Braun J, Sieper J: A single nonamer from the Yersinia $60-\mathrm{kDa}$ heat shock protein is the target of HLA-B27-restricted CTL response in Yersinia-induced reactive arthritis. J Immunol 1997, 159:5715-5723.

55. Turner MJ, Delay ML, Bai S, Klenk E, Colbert RA: HLA-B27 upregulation causes accumulation of misfolded heavy chains and correlates with the magnitude of the unfolded protein response in transgenic rats: implications for the pathogenesis of spondylarthritis-like disease. Arthritis Rheum 2007, 56:215223.

56. Atagunduz $\mathrm{P}$, Appel $\mathrm{H}$, Kuon $\mathrm{W}$, Wu P, Thiel A, Kloetzel PM, Sieper J: HLA-B27-restricted CD8 ${ }^{+} \mathrm{T}$ cell response to cartilage-derived self peptides in ankylosing spondylitis. Arthritis Rheum 2005, 52:892-901.

57. Khan MA, Mathieu A, Sorrentino R, Akkoc N: The pathogenetic role of HLA-B27 and its subtypes. Autoimmun Rev 2007, 6: 183-189.

58. Brown MA: Human leucocyte antigen-B27 and ankylosing spondylitis. Intern Med J 2007, 37:739-740.

59. Wellcome Trust Case Control Consortium; Australo-Anglo-American Spondylitis Consortium (TASC), Burton PR, Clayton DG, Cardon LR, Craddock N, Deloukas P, Duncanson A, Kwiatkowski DP, McCarthy MI, Ouwehand WH, Samani NJ, Todd JA, Donnelly P, Barrett JC, Davison D, Easton D, Evans DM, Leung HT, Marchini JL, Morris AP, Spencer CC, Tobin MD, Attwood AP, Boorman JP, Cant B, Everson U, Hussey JM, Jolley JD, Knight AS, Koch K, et al.: Association scan of 14,500 nonsynonymous SNPs in four diseases identifies autoimmunity variants. Nat Genet 2007, 39:1329-1337. 